\title{
The Doctor I Became During the COVID-19 Pandemic
}

\author{
Amaya Llorente-Cháveza* \\ Department of Internal Medicine Residency Program, Instituto Nacional de Ciencias Médicas y Nutrición Salvador Zubirán, \\ México
}

\section{PERSPECTIVE}

I was a third-year resident of Internal Medicine when the COVID-19 pandemic broke out. I never imagined the scale it would have until one Monday of March, when the two heads of residents spoke with us. They explained to us that our hospital had been selected as one of the national reference centers in Mexico to care for patients with COVID-19. What I did not know at the time was that my life was going to change completely.

The pandemic had reached my country and, as residents, we were the first line of battle against it. No one asked us if we were ready to fight it, everyone assumed we were and so did we.

The first week we were divided into multiple teams to attend patients in the Emergency Room and in the Intensive Care Unit. As a third-year resident, I was chosen as the team leader, which implied a lot of responsibility towards my patients and my team members that were from different specialties.

The night before my first guard, I remember not being able to sleep. I had read everything I could about invasive mechanical ventilation, vasopressors, and rapid intubation sequence to feel prepared. I was not, however. No one is prepared for death.

I left my house at 6:30 in the morning and I was surprised since there were no people on the streets; the city was flooded by an enormous silence. As soon as I entered the hospital, I realized there was a lot of noise in there.

Until then, I had always enjoyed going to the hospital, talking to other doctors, and attending patients every day. However, that day I was filled with a sense of fear and foreboding. What if one of my fellow residents got infected? What would happen if I got infected? And what was unimaginable for me: what would happen if I infected my family? These thoughts accosted me every moment of the day.
That first guard I learned how it was going to be a doctor during a pandemic. It was shocking for me to see the Emergency Room full of patients. I heard patients coughing, I saw the anguish on the faces of my fellow residents, and many patients died. In the Intensive Care Unit, I could see all beds occupied by intubated patients. Everything I had studied helped me to survive that moment; however, it did not help me to understand the reality of the situation. We were fighting an unknown enemy, which we neither knew how to deal with, nor how to treat.

At dawn, my worst nightmare happened. One of our intubated patients was not responding to our medical treatment. How was I supposed to tell this news to the family? My patient was someone's dad, husband, son, and friend. He was not another number in the death toll in my country, he was a person who had not been able to say goodbye to his family. The last time he saw them was when they left him outside the hospital because he had a cough and was short of breath. Neither he nor his family knew at the time that he would end up intubated and that if he died, he would do so alone in a hospital room.

I remember thinking about what would happen if that patient was my dad, my mom, or my sister. I decided to accompany my patient and took a cell phone inside. I dialed the family and put the cell phone near his ear. His wife told him: we love you, keep fighting, we are waiting for you at home. An hour later, my patient had passed away. I remember that I was with him that whole hour, that I took his hand and told him to be calm, and that I would be by his side till the last moment.

When I got home from my guard, I cried. I felt guilty for his death. I wondered if I could have done something else to save him or if it had been my mistake, and I kept thinking of a different scenario where my patient could return home.

\begin{tabular}{|l|l|} 
Quick Response Code: & $\begin{array}{l}\text { Address for correspondence: Amaya Llorente-Chávez, Department of Internal } \\
\text { Medicine Residency Program, Instituto Nacional de Ciencias Médicas y Nutrición } \\
\text { Salvador Zubirán, Mexico }\end{array}$ \\
\cline { 2 - 2 } & $\begin{array}{l}\text { Received: May 18,2021 Published: June 07, 2021 } \\
\text { How to cite this article: Amaya LC. The Doctor I Became During the COVID-19 Pandemic. } \\
\text { 2021-3(3) OAJBS.ID.000291. DOI: 10.38125/OAJBS.000291 }\end{array}$ \\
\hline
\end{tabular}


The pandemic became the greatest personal, emotional, and professional challenge I have ever had in my life. Every day for a year I experienced the different facets of death. Patients who came to the hospital in cardiac arrest, those who had complications during the hospitalization, those who had been intubated for months and, what was worse, those who died because there were no longer beds available to intubate them on.

I learned about the despair of families, the sadness of unexplained deaths, and the inability to cure most COVID-19 patients. Little by little I started having trouble sleeping, and I had nightmares where I would dream of ventilators repeatedly. I was afraid to go to the hospital and living with personal protective equipment was intolerable. Guards were 24 hours or more and I ended up exhausted. It was not just the emotional stress, but the physical stress, and the heat and pain of wearing personal protective equipment for many hours.

During the pandemic, I moved out of my house. I could not take the risk of infecting my family. The only people I saw were other residents at the hospital. One day I decided to tell one of my colleagues how I felt. To my surprise, he told me that he felt the same way as me, and suddenly we realized that everyone else was dealing with the same emotions. The residents became my second family, my work team, and my friends. They really understood what it was like to experience the pandemic from inside a hospital. I felt as part of a great team, in which every member was trying her or his best. Thanks to the work of all the residents, our hospital became the best center to attend patients with COVID-19.

When I started my medical degree, I never thought I would experience a pandemic. This year taught me about teamwork, courage, and resilience, about love and empathy. Residency has been a long road, yet despite living with COVID-19, the past year was one of the worst and best years of my life because of what I learned. I understood that even though no more medical treatment can be carried out, there is still much to do, because we do not treat COVID-19, we treat patients.

One year after the pandemic, I have discovered the doctor I want to be. I no longer feel guilty if a patient dies, because I know that I made my best possible effort to help him. I will never forget the first patient we managed to extubate. I remember when I removed the endotracheal tube, and the patient looked at me. I told her that she would soon be able to see her family. She smiled at me, and I saw a tear slide down her cheek. That day I also cried, but now of joy.

I always want to remember what 2020 was like for me, but above all, I always want to cry and care for my patients and never forget that humanism in Medicine is its most important part. And above all, I understood that absolutely all the road traveled has been worth it. 